\title{
Pengembangan Taman Kupu-Kupu Sebagai Asset Pemerintah Bandar Lampung
}

\author{
Hesti Widi Astuti(i), Husna Purnama ${ }^{(1)}$, Maria Elina ${ }^{(1)}$, Suwandi $^{(2)}$ \\ Universitas Sang Bumi Ruwa Jurai \\ Institut Informatika Dan Bisnis Darmajaya \\ hesti172112@gmail.com
}

\begin{abstract}
Abstrak.
Wisata yang ada di Kota Bandar Lampung antara lain, bukit sakura, penangkaran rusa dan taman kupu-kupu. Objek penelitian dari pariwisata yang ada di Kota Bandar lampung adalah Taman Kupu-kupu. Tujuan penelitian pada penelitian ini adalah: Menentukan konsep pengembangan pariwisata mempengaruhi asset pemerintah Bandar Lampung; Menentukan upaya pengembangan pariwisata mempengaruhi asset pemerintah Bandar Lampung; Menentukan konsep pengembangan pariwisata dan upaya pengembangan pariwisata terhadap asset pemerintah Bandar Lampung. Alat analisis dalam penelitian ini adalah Uji validitas, uji reliabilitas, uji normalitas, uji regresi linier berganda dan uji determinasi. Hasil penelitian untuk uji validitas dan reliabilitas dalam penelitian untuk semua variabel adalah valid dan reliabel. Hasil uji t dan uji $F$ untuk konsep dan pengembangan mempengaruhi aset pemerintah sedangkan untuk uji determinasi konsep dan pengembangan secara bersama-sama mempengaruhi aset pemerintah.
\end{abstract}

Kata kunci: Asset Pemerintah, Konsep Pengembangan Pariwisata, Upaya Pengembangan Pariwisata.

There are tours in Bandar Lampung City, among others, cherry hills, deer breeding and butterfly gardens. The object of research from tourism in Bandar Lampung City is the Butterfly Park. The research objectives in this study can be described as follows: Determining the concept of tourism development affecting government assets in Bandar Lampung; Determining tourism development efforts to affect the assets of the Bandar Lampung government; Determine the concept of tourism development and tourism development efforts towards the Bandar Lampung government assets. The population in this study is the people of Bandar Lampung and the sample is the people of Bandar Lampung who have visited the Butterfly Park. The analysis tools in this research are validity test, reliability test, normality test, multiple linear regression test and determination test.The results of the study to test the validity and reliability in the study for all variables were valid and reliable. The results of the $T$ test and $F$ test for the concept and development, affect the asset of goverment, while for the determination test the concept and development jointly affect the goverment asset.

Keywords: Tourism Development Concept, Tourism Development Efforts, Government Assets.

\section{PENDAHULUAN}

Indonesia merupakan negara yang kaya akan keindahan alam, flora dan fauna serta keragaman suku, agama dan ras (SARA) yang memiliki kebudayaan yang berbeda-beda (Parma, 2019), yang semuanya dapat dijadikan sebagai pendapatan negara dalam bentuk devisa negara. Sektor pariwisata di Indonesia hal yang sangat mudah dikembangkan dengan melakukan perbaikan infrastuktur, keamanan dan manajemen yang baik agar mampu menciptakan sektor pariwisata yang diminati wisatawan lokal maupun asing dengan rasa kepuasan yang baik, dalam hal ini maka akan menciptakan rasa yang ingin berwisata kembali, dengan kata lain akan menciptakan dampak positif bagi masyarakat dan Negara (Kristin \& Salam, 2016). Sektor pariwisata sebagai salah satu sektor yang mendorong pertumbuhan ekonomi suatu Negara, tentu mempunyai peran yang strategis yang berkaitan dengan ketersediaan komoditas pendukung kepariwisataan seperti transportasi, akomodasi, hiburan, jasa-jasa dan lain sebagainya ("Kontribusi Sektor Pariwisata Terhadap Gdp Indonesia Tahun 2004 2009," 2014). Sarana prasarana dalam suatu 
objek parisiwata sangatlah penting karena jika ini baik maka wisatawan dapat berlamalama ditempat objek wisata sehingga dapat menambah pendapatan penduduk setempat. UU No. 10 Tahun 2009 tentang kepariwisataan dijelaskan bahwa parisiwata adalah berbagai macam kegiatan wisata dan didukung berbagai fasilitas serta layanan yang disediakan oleh masyarkat pengusaha dan pemerintah (Herdiana, 2020).

Kota Bandar Lampung merupakan salah satu provinsi yang mempunyai objek pariwisata alam yang bagus, kekayaan alam yang ada seperti laut dan gunung. Kekayaan alam inilah yang mempunyai potensi untuk dijadikan objek wisata yang tidak dimiliki oleh provinsi lain sehingga provinsi Lampung menjadi salah satu tujuan wisatawan sebagai provinsi tujuan wisata. Objek wisata ini menjadi asset pemerintah Kota Bandar Lampung. Wisata yang ada di Kota Bandar Lampung antara lain, bukit sakura, penangkaran rusa dan taman kupukupu. Objek penelitian dari pariwisata yang ada di Kota Bandar lampung adalah Taman Kupu-kupu. Pengggasan taman kupu-kupu ini adalah Ansori Djausal dan Herawati Soekardi yang memanfaatkan area di tepi hutan sehingga konsep objek wisata ini menyatu dengan alam.

Koleksi kupu-kupu yang dimiliki Gita Persada ini sebanyak 6.000 spesies kupukupu dari seluruh penjuru dunia yang semuanya dalam kondisi sudah diawetkan dan dipajang di dalam mueseum, sedangkan untuk spesies Sumatera terdiri atas 140 jenis yang ditempatkan di dalam Dome atau sangkar raksasa yang menjadi tempat penangkaran. Dibuka setiap hari pada jam $08.00-17.00$, Taman Kupu-kupu mengenakan tiket masuk sebesar Rp.10.000. Harga tiket masuk yang relatif murah tersebut, pengunjung dapat menikmati sejumlah wahana rekreasi dan wahana belajar yang ada di lokasi, seperti Dome atau Sangkar Kupu-kupu Raksasa, Museum Kupu-kupu, Rumah Pohon Children
Playground, dan sejumlah fasilitas lain, seperti area parkir, Tea House atau kafetaria serta kamar mandi dan toilet.

Begitu memasuki lokasi wisata, tidak jauh dari pintu gerbang dapat ditemui sebuah bangunan dari kayu yang berfungsi sebagai Meseum Kupu-kupu. Di dalamnya Sahabat Silir dapat melihat berbagai jenis kupu-kupu yang telah diawetkan lengkap dengan informasi tentang setiap jenis kupu-kupu tersebut, masih di dalam ruangan yang sama, dapat dijumpai meja, kursi, lukisan dan patung dari kayu yang semuanya berbentuk kupu-kupu. Terdapat pula berbagai macam aksesoris seperti gantungan kunci, cincin, gelang, kalung dan sebagainya yang juga berbentuk kupu-kupu. Asesoris-asesoris tersebut tidak hanya dipajang, tapi juga dijual. Sehingga bagi pengunjung yang berminat, usai mengelilingi seluruh area wisata, harus kembali ke museum jika ingin membeli souvenir berbentuk kupu-kupu.

Sumber belajar tidak hanya dari kupukupu yang sudah diawetkan, tapi juga dari kupu- kupu yang masih hidup untuk melihat proses metamorfosis mulai dari ulat menjadi kepompong, sebelum akhirnya menjadi kupu-kupu. Berbagai jenis kupu-kupu yang masih hidup tersebut ditempatkan di sebuah dome atau sangkar raksasa,di dalam dome ditanamai berbagai jenis tanaman bunga yang menjadi makanan dari kupu-kupu. Sehingga pengunjung yang masuk, selain dapat melihat kepompong-kepompong yang menempel di dedaunan, juga dapat menjadikan tanaman bunga yang indah sebagai background foto. Setelah belajar tentang kupu-kupu, Sahabat Silir dapat bersantai di sebuah balkon luas yang dilengkapi dua buah sofa panjang untuk menikmati keindahan alam sekitar dengan udara yang sejuk.

Jika ingin melihat landskap yang lebih luas di atas ketinggian, tersedia 3 buah rumah pohon. Di atas rumah pohon, indahnya panorama akan dapat lebih dirasakan karena lokasi Taman Kupu-kupu 
Gita Persada berada di kawasan pinggir hutan. Terdapat pula area playground dengan berbagai macam permainan anakanak, tujuh unit kamar mandi dan toilet, serta sebuah kafetaria yang disebut Tea House. Karena Tea House hanya menyediakan makanan dalam bentuk mie instan dan beberapa jenis minuman, bagi Sahabat Silir yang ingin berlama-lama di lokasi, disarankan membawa bekal sendiri dari rumah, sebab tidak ada larangan bagi pengunjung untuk membawa makanan dari luar.

Sarana prasarana yang sudah disediakan oleh pengelola sudah baik, yang dirasa kurang adalah alat transportasi umum menuju objek wisata masih kurang, wisatawan bisanya menggunakan mobil pribadi dan motor, disekitar lingkungan taman kupu-kupu masih belum terlalu ramai sehingga pemanfaatan masyarakat dalam pariwisata masih kurang. Hasil penelitian yang dilakukan oleh Meiridho mengenai peluang besar industri pariwisata di Lampung adalah 1. Potensi besar Industi Pariwisata yang ada Lampung perlu terus digali dan dikembangkan dengan melihat kekuatan, kelemahan, peluang dan ancaman pada ODTW (objek daerah tujuan wisata) tersebut. 2. Pemerintah dan masyarakat Lampung sudah saatnya menjadikan Industri Pariwisata sebagai prioritas unggulan untuk percepatan pembangunan dan kemajuan perekonomian masyarakat Lampung. 3. Meningkatkan dan melakukan pengembangan sarana prasarana penunjang dan manajemen Objek Daya Tarik Wisata (ODTW). 4. Membangun citra pariwisata dengan menitik beratkan wisata alam, budaya, religi, dan wisata sejarah. Dalam pengembangan juga bisa menjadi wisata desa, agro wisata, kampung adat atau nelayan, ritual, kuliner, tari tradisional dan wisata kriya (hasil kerajinan). 5. Membangun data base, koordinasi lintas sektoral dan jaringan pemasaran. 6 . Membangun pemahaman dan peran serta masyarakat Lampung agar mendukung dan menjadi masyarakat yang sadar wisata dan berwawasan global tanpa menghilangkan identitas budaya lokal. (Meiridho et al., 2018). Fenomena inilah yang menjadi dasar peneliti untuk mengambil penelitian ini agar taman kupu-kupu bisa menjadi lebih mudah dikunjungi oleh masyarakat luas dan masyarakat sekitar bisa meningkatkan pendapatannya dari kunjungan wisatawan, dengan adanya sarana dan prasarana yang telah disiapkan oleh pihak pengelola, maka akan membuat wisatawan merasa nyaman ketika berkunjung ke objek wisata (Marianti, 2019).

Rumusan masalah pada penelitian ini adalah sebagai berikut: Bagaimana konsep pengembangan pariwisata mempengaruhi asset pemerintah Bandar Lampung?; Bagaimana upaya pengembangan pariwisata berpengaruh terhadap asset pemerintah Bandar Lampung?; Bagaimana konsep pengembangan pariwisata dan upaya pengembangan pariwisata berpengaruh terhadap asset pemerintah Bandar Lampung?

Tujuan penelitian pada penelitian ini dapat diuraikan seperti di bawah ini : menentukan konsep pengembangan pariwisata mempengaruhi asset pemerintah Bandar Lampung; menentukan upaya pengembangan pariwisata mempengaruhi asset pemerintah Bandar Lampung; Menentukan konsep pengembangan pariwisata dan upaya pengembangan pariwsata terhadap asset pemerintah Bandar Lampung.

Modal pariwisata perlu dimanfaatkan dalam pengembangan dan meningkatkan mutu daerah tujuan wisata, untuk melaksanakan terciptanya kondisi yang diharapkan dalam mengembangkan pariwisata maka perlu adanya sapta pesona (Suryani, 2017). Tujuan pengembangan pariwisata di Indonesia sesuai dengan instruksi presiden yaitu: a. Meningkatkan pendapatan devisa negara pada khususnya 
dan pendapatan negara dan masyarakat pada umumnya, perluasan kesempatan kerjsa serta mendorong kegiatan- kegiatan industri penunjang dan industri-industri sampingan lainnya; b. Memperkenalkan dan mendayagunakan keindahan alam dan kebudayaan Indonesia; c. Meningkatkan persaudaraan/persahabatan nasional dan internasional. Pengembangan suatu daerah dapat disesuaikan oleh pemerintah daerah dengan potensi dan kekhasan daerah masing-masing (Prasetya \& Rani, 2014).

Berdasarkan peraturan daerah provinsi Lampung No. 6 tahun 2011 tentang Kepariwisataan pasal 11 yang menjadi acuan dalam pengembangan kawasan pariwisata didasarkan pada kriteria : a. Aksesibilitas, b. Amenitas/fasilitas,

Ancillary/kelembagaan daya tarik wisata; $d$. Kesiapan masyarakat, f. Era/trend yang berkembang. Industri pariwisata ini merupakan suatu industri yang biasanya dihubungkan secara langsung dengan pembangunan ekonomi. Industri ini memiliki hubungan multi dimensi yang tidak hanya terkait erat dengan bidang ekonomi saja, tetapi hampir setiap bidang pembangunan nasional bersentuhan dan erat kaitannya dengan industri pariwisata ini. Pengertian Industri Pariwisata menurut Undang-undang Pariwisata Nomer 10 tahun 2009, adalah organisasi usaha pariwisata yang saling terkait dalam rangka menghasikan barang dan / atau jasa bagi pemenuhan kebutuhan wisatawan dalam penyelenggaraan wisata. Definisi lain tentang Industri Pariwisata adalah merupakan kumpulan berbagai macam bidang usaha yang secara bersama - sama menghasilkan produk - produk maupun jasa / pelayanan yang nantinya baik langsung maupun tidak langsung akan dibutuhkan oleh wisatawan. (Zahrulianingdyah, 2018), lebih-lebih hadirnya industri jasa ini merupakan manifestasi kehadiran aktifitas manusia seperti juga industri-industri dalam bidang-bidang pembangunan yang lainnya. mengingat begitu eratnya dengan berbagai bidang lain dalam proses pembangunan nasional maka aktifitas kepariwisataan bisa dikembangkan secara optimal sehingga pengembangan merupakan suatu proses pelaksanaan program yang terus meningkat ke arah puncak capaian sesuai dengan tujuan yang telah dicanangkan. Jika kita sedikit menengok pada Pembukaan UUD 1945 maka ada amanah yang kiranya dapat dijadikan capaian tujuan itu, yakni terwujudnya kesejahteraan umum, mencerdaskan kehidupan bangsa dan ikut mewujudkan perdamain dunia. Kata-kata kunci dari Pembukaan UUD 1945 tersebut penting dikemukakan agar industri pariwisata ini, terutama program-program kegiatannya, tidak keluar dari cita-cita mendirikan negara ini. Untuk itu kita harus membangun cara pandang baru tentang pariwisata sebagai unsur utama perekonomian nasional, apalagi bila kita ingin mengembangkan industri pariwisata sebagai alat dukung bagi meningkatkan harkat dan martabat negara bangsa di tengah pergaulan dunia internasional yang memiliki daya saing. Ada beberapa langkah strategis yang kiranya dapat dijadikan pertimbangan dalam membangun cara pandang ke arah itu. Dalam hal ini industri pariwisata dapat dipandang sebagai penentu: 1) Meningkatnya kesejahteraan masyarakat bangsa. 2) Terbentuknya kepribadian bangsa Indonesia. 3) Terjaganya dan terpeliharanya keutuhan negara Kesatuan Republik Indonesia. 4) Terjalinnya hubungan antar bangsa-bangsa di dunia secara damai, harmonis dan berperadaban. Terbinanya kreatifitas masyarakat bangsa dalam berbagai segi kehidupan. 5) Terbangunnya keseimbangan hidup masyarakat bangsa dengan keberlangsungan kehidupannya. 6) Terbangkitkannya spiritualitas masyarakat bangsa. Terjalinnya kebersamaan dan kepedulian untuk percepatan optimalisasi sektor pariwisata. 
Beberapa cara di atas adalah langkah yang dinilai efektif untuk merubah cara pandang masyarakat tentang pariwisata sehingga nantinya pariwisata dapat dijadikan sebagai suatu sektor industri jasa yang strategis dalam pembangunan ekonomi nasional. Sektor industri pariwisata sekarang ini harus beradaptasi dengan metode yaitu media promosi dan pemasaran online. (Atiko, G., Sudrajat, R. H., \& Nasionalita, 2016) telah melakukan sebuah penelitian yang mengkaji penggunaan media sosial (online) seperti Instagram untuk mempromosikan tujuan wisata di Indonesia kemudian disertai visualisasi untuk tujuan mendapatkan target wisatawan yang lebih luas (An, 2021), dalam upaya pengembangan pariwisata memiliki beberapa cara yaitu: a) Analisis Rantai Nilai Wisata Alam; Analisis rantai nilai dilakukan untuk mengidentifikasi faktor, peran, hubungan, peluang dan hambatan, dorongan untuk upgrading dan aliran informasi serta manfaat yang didapat oleh masing-masing faktor yang terkait dalam rantai tersebut. 2) Pengembangan Strategi Kompetitif; pengembangan strategi kompetitif adalah pencapaian posisi kompetitif yang diinginkan, untuk menciptakan keuntungan guna mendukung dalam kekuatan yang menentukan persaingan. 3) Implementasi Rencana Pengembangan; Kebijakan (policy) umumnya digunakan untuk memilih dan menunjukkan pilihan terpenting untuk mempererat kehidupan, baik dalam kehidupan organisasi kepemerintahan maupun privat. Kebijakan harus bebas dari konotasi atau nuansa yang dicakup dalam kata politis (political), yang sering diyakini mengandung makna keberpihakan akibat adanya kepentingan. Kebijakan sebuah ketetapan berlaku dan dicirikan oleh perilaku yang konsisten serta berulang, baik dari yang membuatnya maupun yang menaatinya (yang terkena kebijakan). Adapun kebijakan publik (public policy) merupakan rangkaian pilihan yang lebih kurang saling berhubungan (termasuk keputusan-keputusan yang tidak bertindak) yang dibuat oleh badan dan pejabat pemerintah. Evaluasi merupakan proses dari pengumpulan dan analisis informasi mengenai efktifitas dan dampak suatu program dalam tahap tertentu sebagai bagian atau keseluruhan dan juga mengkaji pencapaian program (Suaib, 2016).

Asset adalah sumber daya ekonomi yang dikuasai dana atau dimiliki oleh pemerintah sebagai akibat dari peristiwa masa lalu dan dari mana manfaat ekonomi dan atau sosial di masa depan diharapkan dapat diperoleh, baik oleh pemerintah maupun masyarakat, serta dapat diukur dalam satuan uang, termasuk sumber daya nonkeuangan yang diperlukan untuk penyediaan jasa bagi masyarakat umum dan sumber-sumber daya yang dipelihara karena alasan sejarah dan budaya. Taman kupukupu diharapkan dapat menjadi asset daerah Lampung untuk meningkatkan pendapatan daerah dalam sektor pariwisata. Pendapatan obyek pariwisata adalah merupakan sumber penerimaan obyek pariwisata yang berasal dari retribusi karcis masuk, retribusi parkir dan pendapatan lain-lain yang sah berasal dari obyek pariwisata tersebut.

Menurut UU No. 34 tahun 2000 tentang perubahan UU No. 18 tahun 1997 bahwa pajak daerah dan retribusi daerah merupakan salah satu sumber pendapatan daerah yang penting guna membiayai penyelenggaraan pemerintahan daerah dan pembangunan daerah. Pajak daerah atau yang disebut pajak adalah iuran wajib yang dilakukan oleh pribadi atau badan kepala daerah tanpa imbalan langsung yang seimbang, yang dapat dipaksakan berdasarkan peraturan perundang-undangan yang berlaku, yang digunakan untuk membiayai penyelenggaraan pemerintah daerah dan pembangunan daerah.

Retribusi daerah merupakan salah satu sumber pendapatan daerah yang penting guna membiayai penyelenggaraan daerah 
dan pembangunan daerah untuk menetapkan Otonomi Daerah Paksaan di sini bersifat ekonomis karena siapa saja yang tidak merasakan jasa balik dari pemerintah tidak akan dikenakan iuran itu. Kemudian diuraikan pula definisi dan pengertian berkaitan dengan retribusi yaitu dikutip Sproule-Jones dan White,(1997) mengatakan bahwa retribusi adalah semua bayaran yang dilakukan bagi perorangan dalam menggunakan layanan yang mendatangkan keuntungan langsung dari layanan itu. Lebih lanjut dikatakan bahwa retribusi lebih tepat dianggap pajak konsumsi dari pada biaya layanan: bahwa retribusi hanya menutupi biaya opersional saja, Menurut Queen (1998:2) menerangkan bahwa: "suatu tanggapan menekankan memperjelas kenyataan bahwa masyarakat memandang retribusi sebagai bagian progam bukan sebagai pendapatan daerah dan bersedia membayar hanya bila tingkat layanan dirawat dan ditingkatkan. Berdasarkan hal tersebut dapat disimpulkan bahwa bagian yang mudah dalam menyusun retribusi yaitu menghitung dan menetapkan tarif. Bagian tersulit adalah menyakinkan masyarakat (publik) tanpa diluar kesadaran mereka tarif tetap harus diberlakukan.

\section{METODE PENELITIAN}

Penelitian ini menggunakan teknik pengambilan sampel dengan metode purposive sampling. Metode purposive sampling adalah teknik penentuan sampel bila semua anggota populasi digunakan sebagai sampel (Al Islami, 2019). Purposive sampling (juga dikenal sebagai judgment, selective atau subyejtif sampling) adalah teknik pengambilan sampel dimana peneliti mengandalkan penilaiannya sendiri ketika memilih anggota populasi untuk berpartisipasi dalam penelitian. Sampel dalam penelitian adalah 100 responden.

Analisis data menggunakan : Uji validitas untuk menunjukkan masingmasing instrumen benar-benar mengukur faktornya dan uji reliabilitas untuk mengukur sejauh mana alat pengukur data dapat dipercaya atau diandalkan (Amanda et al., 2019); Reliabilitas adalah ukuran yang menujukkan bahwa alat ukur yang digunakan dalam penelitian keperilakukan mempunyai keandalan sebagai alat ukur, diantaranya di ukur melalui konsistensi hasil pengukuran dari waktu ke waktu jika fenomena yang diukur tidak berubah (Janti, 2014). Uji normalitas bertujuan untuk mengetahui apakah data berdistribusi normal atau tidak. Hal ini penting diketahui berkaitan dengan ketetapatan pemilihan uji statistik yang akan dipergunakan. Untuk menguji normalitas data dalam penelitian ini digunakan uji Kolmogorov-Smirnov (Jonaidi, 2012); Model regresi yang digunakan dalam penelitian ini adalah analisis regresi linear berganda. Analisis regresi linear berganda dilakukan dengan tujuan untuk mengetahui arah pengaruh konsep dan pengembangan terhadap aset pemerintah, apakah pengaruhnya positif atau negatif.

\section{HASIL DAN PEMBAHASAN}

Untuk mengetahui seberapa jauh konsep dan perkembangan terhadap aset pemerintah dapat diketahui pada tabel $1 \mathrm{di}$ bawah ini.

Tabel 1. Hasil Uji Regresi Linier Berganda

\begin{tabular}{|c|c|c|c|c|c|c|}
\hline \multirow[t]{2}{*}{ Model } & & \multicolumn{2}{|c|}{ Unstandardized Coefficients } & \multirow{2}{*}{$\begin{array}{c}\text { Standardized } \\
\text { Coefficients } \\
\text { Beta }\end{array}$} & \multirow[t]{2}{*}{$\mathrm{t}$} & \multirow[t]{2}{*}{ Sig. } \\
\hline & & B & Std. Error & & & \\
\hline \multirow{2}{*}{1} & (Constant) & 7.737 & 2.144 & & 3.608 & .000 \\
\hline & $\mathrm{X} 1$ & .401 & .096 & .391 & 4.184 & .000 \\
\hline
\end{tabular}




\begin{tabular}{llllll}
\hline $\mathrm{X} 2$ & .295 & .116 & .238 & 2.545 & .012 \\
\hline
\end{tabular}

Dari tabel 1, diperoleh dengan persamaan sebagai berikut:

$$
\mathrm{Y}=7,737+0,401+0,295+\text { et }
$$

Persamaan tersebut memiliki arti apabila konsep pengembangan pariwisata dan upaya pengembangan pariwisata sebesar
0, maka asset pemerintah sebesar 7,737 dan setiap peningkatan konsep pengembangan pariwisat adalah sebesar 0,401. Hasil olah data untuk hasil uji determinan dapat dilihat pada Tabel 2.

Tabel 1. Hasil Uji Regresi Linier Berganda

Model Summary ${ }^{\mathrm{b}}$

\begin{tabular}{lcccc}
\hline Model & $\mathrm{R}$ & $\mathrm{R}$ Square & $\begin{array}{c}\text { Adjusted R } \\
\text { Square }\end{array}$ & $\begin{array}{c}\text { Std. Error of the } \\
\text { Estimate }\end{array}$ \\
\hline 1 & $.534^{\mathrm{a}}$ & .285 & .270 & 2.443 \\
\hline $\begin{array}{l}\text { a. Predictors: (Constant), } \mathrm{X}_{2}, \mathrm{X}_{1} \\
\text { b. Dependent Variable: } \mathrm{Y}\end{array}$ & & & & \\
\end{tabular}

Interpretasi untuk tabel di atas adalah sebagai berikut : nilai koefisien Determinasi atau $\mathrm{R}$ Square adalah sebesar 0,285 atau $28,5 \%$ yang artinya bahwa variabel konsep pengembangan pariwisata $(\mathrm{X} 1)$ dan variabel upaya pengembangan pariwisat (X2) berpengaruh terhadap asset pemerintah sebesar $28,5 \%$, sedangkan sisanya $71,5 \%$ dipengaruhi oleh variabel lain di luar variabel yang tidak diteliti.

Hasil penelitian yang dilakukan oleh Meiridho mengenai peluang besar industri pariwisata di Lampung adalah 1. Potensi besar Industi Pariwisata yang ada Lampung perlu terus digali dan dikembangkan dengan melihat kekuatan, kelemahan, peluang dan ancaman pada ODTW (objek daerah tujuan wisata) tersebut. 2. Pemerintah dan masyarakat Lampung sudah saatnya menjadikan Industri Pariwisata sebagai prioritas unggulan untuk percepatan pembangunan dan kemajuan perekonomian masyarakat Lampung. 3. Meningkatkan dan melakukan pengembangan sarana prasarana penunjang dan manajemen Objek Daya
Tarik Wisata (ODTW). 4. Membangun citra pariwisata dengan menitik beratkan wisata alam, budaya, religi, dan wisata sejarah. Dalam pengembangan juga bisa menjadi wisata desa, agro wisata, kampung adat atau nelayan, ritual, kuliner, tari tradisional dan wisata kriya (hasil kerajinan). 5. Membangun data base, koordinasi lintas sektoral dan jaringan pemasaran. 6 . Membangun pemahaman dan peran serta masyarakat Lampung agar mendukung dan menjadi masyarakat yang sadar wisata dan berwawasan global tanpa menghilangkan identitas budaya lokal. (Meiridho et al., 2018).

Hasil penelitian kami secara metode berbeda dengan penelitian terdahulu yaitu : 1. Penelitian kami dilakukan dengan metode kuantitatif dan metode secara kualitatif digunakan oleh Meiridho, 2. Hasil penelitian kami menggunakan analisis regresi linier berganda sedangkan penelitian Meiridho dengan analisis kualitatif.

Hasil penelitian kami adalah semua variabel bebas mempengaruhi variabel 
terikat walaupun pengaruhnya kecil, sedangkan hasil penelitian Meiridho adalah seperti di atas. Penelitian kami sejalan dengan penelitian oleh Meiridho dilihat dari hasil mengenai pengembangan pariwisata di Lampung dan peningaktan sarana prasarana pariwisata.

\section{KESIMPULAN}

Kesimpulan pada penelitian ini adalah sebagai berikut : Uji secara simultan (Uji T) adalah variabel konsep pengembangan pariwisata dan upaya pengembangan pariwisata mempengaruhi asset pemerintah; Uji $F$ atau uji secara simultan adalah variabel konsep pengembangan pariwisata dan upaya pengembangan pariwisata mempengaruhi asset pemerintah; Hasil uji determinasi berpengaruh sebesar $28,5 \%$.

\section{DAFTAR PUSTAKA}

Al Islami, R. (2019). Pengaruh Stres Kerja, Training, Kepuasan Kerja Dan Budaya Organisasi Terhadap Kinerja Karyawan "Studi Kasus Pt. Ciliandra Perkasa Divisi Biodiesel-Pelintung.

Alfiansyah, A., Karo, P., Usman, K., Sari, L. P., Dewi, R., Simangunsong, B. A., \& Medan, U. N. (2020). Hasil Pembentukan Karakter Siswa pada Sekolah Full Day School. 2.

Amanda, L., Yanuar, F., \& Devianto, D. (2019). Uji Validitas dan Reliabilitas Tingkat Partisipasi Politik Masyarakat Kota Padang. Jurnal Matematika UNAND, 8(1), 179. https://doi.org/10.25077/jmu.8.1.179 $-188.2019$

An, A. (2021). Upaya Pemulihan Industri Pariwisata Dalam Situasi Pandemi Covid -19. 8(1), 22-31.

Herdiana, D. (2020). Rekomendasi Kebijakan Pemulihan Pariwisata
Pasca Wabah Corona Virus Disease 2019 (Covid-19) di Kota Bandung. Jurnal Master Pariwisata (JUMPA), 2019(July), $1-$ 30file:///C:/Users/asus/Downloads/9 8-Article Tex. https://doi.org/10.24843/jumpa.2020 .v07.i01.p01

Janti, S. (2014). Prosiding Seminar Nasional Aplikasi Sains \& Teknologi (SNAST) 2014 Yogyakarta, 15 November 2014 ISSN: 1979-911X. Snast, November, 159.

Jonaidi, A. (2012). Bahan mendeley analisis pertumbuhan ekonomi dan kemiskinan. Kajian Ekonomi, 1(April), 140-164.

Kontribusi Sektor Pariwisata Terhadap Gdp Indonesia Tahun 2004 - 2009. (2014). Economics Development Analysis Journal, 3(2), 362-371. https://doi.org/10.15294/edaj.v3i2.3 844

Kristin, R., \& Salam, R. (2016). Peran Pemerintah Daerah dalam Pengembangan Pariwisata Alam dan Budaya di Kabupaten Tapanuli Utara. 4(1), 79-96.

Marianti. (2019). Pengaruh Sarana Prasarana Pariwisata Terhadap Kepuasan Wisatawan Pada Objek Wisata Permandian Air Panas Lejja Di Kabupten Soppeng.

Parma, I. P. G. (2019). Pariwisata Dan Pengembangan Sumber Daya Manusia. Jurnal Manajemen Perhotelan Dan Pariwisata, 1(1), 33-51.

Peraturan Daerah Provinsi Lampung No. 6 tahun 2011 tentang Pariwisata.

Prasetya, D., \& Rani, M. (2014). Pengembangan Potensi Pariwisata Kabupaten Sumenep, Madura, Jawa Timur (Studi Kasus: Pantai Lombang). Jurnal Politik Muda, 3(3), 412-421. 